\title{
Paediatric home care in the UK
}

\author{
Maybelle A Tatman, Caroline Woodroffe
}

\begin{abstract}
Paediatric home care services in the UK were ascertained in 1991 and 1992. Respondents from 209 (97\%) UK health districts and boards identified 62 general and 124 specialist paediatric home care services by January 1993, 15\% having opened in the previous year.

Of all UK children, $30 \%$ lived in a district with a general home care service. Five health regions had only specialist services. Districts differed widely in the availability of home care for different disorders.
\end{abstract}

The home care services were small, general services employing a mean (SD) of $2.5(1.6)$ whole time equivalent (WTE) nurses, and specialist services $1.3(0.8)$ WTE nurses. Few services were available 24 hours a day. Funding arrangements were diverse and some services had difficulties in obtaining consumables and equipment for home use.

Despite rapid growth there remains considerable scope for the development of paediatric home care throughout the UK. (Arch Dis Child 1993; 69: 677-680)

Wolfson Child Health

Monitoring Unit,

Division of Public

Health: Epidemiology

and Biostatistics,

Institute of Child

Health, 30 Guilford

Street, London

WCIN 1EH

Maybelle A Tatman

Caroline Woodroffe

Correspondence and reprint requests to: Dr Tatman.

Accepted 17 September 1993

Children are spending less time in hospital than previously ${ }^{1}$ and transferring their care to the community is becoming more common. ${ }^{2}$

Paediatric home care services are an organised alternative to traditional provision, enabling suitable children to receive treatment at home which would otherwise be provided in hospital. ${ }^{34}$ During home visits, nurses carry out practical procedures and help parents to perform these tasks themselves, supporting them and providing information on the child's

Table 1 Home care services in the UK, 1993

\begin{tabular}{lccc}
\hline & $\begin{array}{l}\text { Districts } \\
\text { services (total districts) }\end{array}$ & $\begin{array}{l}\text { Percentage of child population } \\
\text { resident in districts with } \\
\text { general services }\end{array}$ & $\begin{array}{l}\text { Specialist } \\
\text { services }\end{array}$ \\
\hline Northern & $0(16)$ & 0 & 10 \\
Yorkshire & $4(16)$ & 37 & 7 \\
Trent & $5(12)$ & 43 & 15 \\
East Anglian & $0(8)$ & 0 & 2 \\
North West Thames & $9(12)$ & 63 & 3 \\
North East Thames & $7(16)$ & 42 & 3 \\
South East Thames & $5(15)$ & 33 & 0 \\
South West Thames & $4(13)$ & 30 & 3 \\
Wessex & $5(10)$ & 48 & 8 \\
Oxford & $8(8)$ & 00 & 6 \\
South Western & $0(12)$ & 31 & 14 \\
West Midlands & $7(22)$ & 30 & 9 \\
Mersey & $2(10)$ & 17 & 7 \\
North Western & $4(19)$ & 21 & 4 \\
Scotland & $2(15)$ & 0 & 1 \\
Wales & $0(8)$ & 0 & 14 \\
Northern Ireland & $0(4)$ & - & 124 \\
Special health authorities & - & 30 & 8 \\
Total & $62(216)$ & & 0 \\
\hline
\end{tabular}

^Health boards in Scotland and Northern Ireland: does not reflect health district mergers after 1991.
Sources for population: OPCS PP1; OPCS PP3; Scottish Health Statistics 1992; 69th Annual Sources for population: OPCS PP1; OPCS PP3;
Report of Registrar General for Northern Ireland. condition. ${ }^{4}$ They provide continuity of care between hospital and community for children with chronic or terminal illnesses and for children with acute illnesses who are discharged early. ${ }^{25}$ General home care services are provided by paediatric community nurses whereas home care for children with specific conditions is provided by clinical nurse specialists, based either at district level or in a regional centre.

We describe general and specialist services for children in the UK.

\section{Methods}

A postal survey of all 216 UK health districts and boards, excluding special health authorities, was carried out in 1991. In each district, the senior community paediatrician, ${ }^{6}$ or, where no such post could be identified, the public health physician or community nurse manager, ${ }^{7}$ was asked to identify all available paediatric home care services. The nurse in charge of each of these services was asked to complete a postal questionnaire, which included the date the service started, its base (hospital or community), funding, staffing, and criteria for accepting referrals. Respondents in general services were asked to estimate the nursing time allocated to different types of care. Where possible those not returning the questionnaire were interviewed.

Subsequently the nurses in charge of all the identified services were asked to update a list of services in their region. More services were identified, for all of which basic details of location and referral criteria were obtained.

\section{Results}

By the end of 1991 we had identified 53 general and 77 specialist home care services in replies received from 209 (97\%) districts. Updating identified a further 56 services, of which 29 (one general and 28 specialist) had not been reported earlier and 27 (eight general and 19 specialist) were new. Thus by January 1993, we knew of 62 general and 124 specialist services, of which $15 \%$ had started in the previous year. New services were being planned in 15 health districts.

The provision of home care varied among regions with five having only specialist services (table 1). Overall $30 \%$ of children aged 0-14 years lived in a district with a general home care service, assuming that there were no such services for the $2.6 \%$ of children in nonresponding districts.

Compared with specialist services, the general home care services were more likely to work from a base in the community, to work only within their own district, and to accept referrals from general practitioners, com- 
Table 2 Characteristics of general and specialist services; figures are number $(\%)$

\begin{tabular}{lll}
\hline & $\begin{array}{l}\text { General services } \\
(n=62)\end{array}$ & $\begin{array}{c}\text { Specialist services } \\
(n=124)\end{array}$ \\
\hline $\begin{array}{l}\text { Hospital based } \\
\text { Community based }\end{array}$ & $\begin{array}{l}42(68) \\
\text { Referral sources } \\
\begin{array}{l}\text { Hospital staff } \\
\text { General practitioners or } \\
\text { community health }\end{array}\end{array}$ & $\begin{array}{c}119(96) \\
5(4)\end{array}$ \\
$\begin{array}{l}\text { staff } \\
\text { Parents, teachers, or }\end{array}$ & $56(90)$ & $124(100)$ \\
$\quad$ social workers & $28(45)$ & $37(30)$ \\
$\begin{array}{l}\text { Catchment area of service } \\
\text { Single district }\end{array}$ & $52(84)$ & $15(12)$ \\
$\begin{array}{l}\text { Own and neighbouring } \\
\text { districts }\end{array}$ & $10(16)$ & $46(37)$ \\
$\begin{array}{l}\text { Regional } \\
\text { Supraregional }\end{array}$ & 0 & $27(22)$ \\
& 0 & $40(32)$ \\
\hline
\end{tabular}

munity health staff, and parents (table 2). Specialists were predominantly hospital based and two thirds provided a service to more than one district.

The specialist regional and supraregional home care services mainly treated children with cancer, cystic fibrosis, or severe chronic disorders. District level specialists also included those providing neonatal care and treating children with diabetes or asthma (table 3 ).

We obtained further details of working arrangements from $48(90 \%)$ general and 47 $(61 \%)$ specialist services of those identified in 1991.

Details of the conditions treated were obtained from 43 general services (table 4). None of the main groups of conditions given in the table was treated regularly by every general service; most services combined the care of severe and life threatening illnesses with the management of common conditions such as

Table 3 Specialist services, by conditions treated and catchment area

\begin{tabular}{lcccc}
\hline & $\begin{array}{l}\text { Total } \\
\text { No }(\%) \text { of } \\
\text { services }\end{array}$ & $\begin{array}{l}\text { Regional and } \\
\text { supraregional } \\
\text { services }\end{array}$ & $\begin{array}{l}\text { Services } \\
\text { covering more } \\
\text { than one } \\
\text { district }\end{array}$ & $\begin{array}{l}\text { Services } \\
\text { covering a } \\
\text { single } \\
\text { district }\end{array}$ \\
\hline $\begin{array}{l}\text { Condition } \\
\text { Cancer and life threatening illnesses }\end{array}$ & $31(25)$ & 11 & 8 & 12 \\
$\begin{array}{l}\text { Cystic fibrosis and other severe } \\
\text { respiratory disorders }\end{array}$ & $27(22)$ & 17 & 3 & 3 \\
$\begin{array}{l}\text { Neonatal disorders } \\
\text { Diabetes }\end{array}$ & $25(20)$ & 1 & 3 & 21 \\
$\begin{array}{l}\text { Asthma } \\
\text { Other medical: infectious diseases, } \\
\quad \text { blood, skin, renal, endocrine, and }\end{array}$ & $3(7)$ & 0 & 3 & 6 \\
$\begin{array}{l}\text { metabolic disorders } \\
\begin{array}{l}\text { Surgical conditions (for example } \\
\text { neurosurgery, cardiothoracic, }\end{array}\end{array}$ & $23(19)$ & 17 & 0 & 3 \\
$\begin{array}{l}\text { neonatal surgery) } \\
\begin{array}{l}\text { Orthopaedics } \\
\text { Total }\end{array}\end{array}$ & $5(4)$ & 5 & 6 & 0 \\
\hline
\end{tabular}

Table 4 General home care services: conditions treated and nursing time allocated to each condition

\begin{tabular}{lll}
\hline & $\begin{array}{l}\text { No (\%) of } \\
\text { general services } \\
\text { treating each } \\
\text { condition }\end{array}$ & $\begin{array}{l}\text { Mean (range) } \\
\text { WTE/100000 } \\
\text { district resident } \\
\text { children aged } \\
0-14\end{array}$ \\
\hline Condition & $32(74)$ & $0 \cdot 5(0 \cdot 1-2 \cdot 9)$ \\
\hline Cancer and life threatening illnesses & $30(70)$ & $0 \cdot 8(0 \cdot 2-3 \cdot 4)$ \\
Cystic fibrosis and other severe respiratory disorders & $14(33)$ & $0 \cdot 5(0 \cdot 2-1 \cdot 2)$ \\
Neonatal disorders & $22(51)$ & $0 \cdot 8(0 \cdot 1-2 \cdot 8)$ \\
Diabetes & $36(74)$ & $0 \cdot 5(0 \cdot 1-2 \cdot 6)$ \\
Asthma & $38(88)$ & $1 \cdot 4(0 \cdot 1-3 \cdot 8)$ \\
Other medical: infectious diseases, blood, skin, renal, & $31(72)$ & $0.9(0 \cdot 1-2 \cdot 2)$ \\
endocrine, and metabolic disorders & $13(30)$ & $0 \cdot 2(0 \cdot 1-0 \cdot 5)$ \\
Surgical conditions & &
\end{tabular}

Estimates provided by general services from 43 districts.
Table 5 Qualifications of home care nurses; figures are number (\%)

\begin{tabular}{lcc}
\hline & $\begin{array}{l}\text { Generalist } \\
\text { nurses } \\
(n=118)\end{array}$ & $\begin{array}{l}\text { Specialist } \\
\text { nurses } \\
(n=72)\end{array}$ \\
\hline $\begin{array}{lcc}\text { Registered sick children's nurse } \\
\text { District nursing certificate }\end{array}$ & $112(95)$ & $58(81)$ \\
Health visiting certificate & $51(43)$ & $6(8)$ \\
$10(8)$ & $17(24)$
\end{tabular}

asthma and with postoperative care, especially after short stay surgery. Some services also visited children with diabetes, or neonates, or supervised orthopaedic treatment such as traction. Even after allowing for the size of the catchment population, a wide range existed among the general home care services in the quantity of nursing time allocated to each condition.

General services employed one to nine nurses, with a mean (SD) of $2.5(1.6)$ whole time equivalents (WTE), or $4.9(2 \cdot 9)$ WTE per 100000 resident children aged 0-14. Eleven services had one WTE or less. Services treating children from other districts usually gave advice rather than practical care and had the same mean staffing as services confined to their own district. Specialist services were smaller than general services, with a mean (SD) of 1.3 $(0 \cdot 8)$ WTE. Home care nurses all had previous experience in hospital paediatrics and many had a qualification in district nursing or health visiting in addition to registration as sick children's nurses (table 5). One general service employed a community paediatric registrar, but otherwise both hospital and community based nurses obtained clinical support primarily from hospital paediatricians.

Services provided mostly daytime cover, those with more staff providing a seven day service (table 6). Only six services were continuously on call, although in special circumstances, such as terminal illness, 31 (65\%) general and $20(43 \%)$ specialist services provided out of hours cover.

Funding arrangements were diverse (table 7). Most services did not hold their own budget and 10 general services supplied children at home with consumables and equipment intended for ward use. There were particular problems in providing these items locally when children were discharged from tertiary hospitals.

\section{Discussion}

Paediatric home care provision increased during the survey period. This growth may indicate pressure on inpatient services as well as changes in paediatric practice. Currently the transfer of hospital care to the community is advocated, inpatient stays have become

Table 6 Hours covered by home care nurses; figures are number (\%)

\begin{tabular}{lcc}
\hline Hours & $\begin{array}{c}\text { General } \\
\text { services }\end{array}$ & $\begin{array}{c}\text { Specialist } \\
\text { services }\end{array}$ \\
\hline Daytime Monday to Friday & $25(52)$ & $36(77)$ \\
Daytime seven days a week & $21(44)$ & $7(15)$ \\
Continuous on call service & $2(4)$ & $4(8)$ \\
Total & 48 & 47 \\
\hline
\end{tabular}


Table 7 Funding sources of home care services; figures are number (\%)

\begin{tabular}{llc}
\hline Source & $\begin{array}{l}\text { General } \\
\text { services }\end{array}$ & $\begin{array}{l}\text { Specialist } \\
\text { services }\end{array}$ \\
\hline $\begin{array}{l}\text { Hospital paediatric unit } \\
\text { Community unit }\end{array}$ & $19(40)$ & $32(68)$ \\
$\begin{array}{l}\text { Combined hospital and community } \\
\text { funding }\end{array}$ & $18(38)$ & $9(19)$ \\
Total & 48 & 47
\end{tabular}

Charitable funding and inner city projects contributed substantially to seven general and 12 specialist services. One hospital based general service was partly funded by the Family Health Services Authority. One specialist nurse worked on a voluntary basis.

shorter, ${ }^{8}$ and day admission is preferred to overnight stay in hospital. ${ }^{9-11}$ Parents learn to care for their sick child while in hospital and new technology enables more procedures to be done at home. ${ }^{12-14}$ Changing morbidity patterns may also have increased the demand for home care. In the Oxford region, respiratory disorders and sequelae of neonatal intensive care have contributed to an increasing rate of admission of children to hospital, ${ }^{15}$ and bed use by children with malignancy and congenital metabolic disorders has increased. ${ }^{1}$ These trends may reflect rising asthma prevalence ${ }^{16}$ and greater survival of premature babies ${ }^{17}$ and of children with neoplasms ${ }^{18}$ or cystic fibrosis. ${ }^{19}$

The provision and scope of paediatric home care services varied from region to region and from district to district. The general services worked mainly in their own health districts and although aiming to treat children with a wide range of conditions they were often selective. Specialist home care services for cancer and cystic fibrosis were provided over a wide geographical area from regional centres but specialist provision for children with other conditions was patchy.

Regions with fewer general services did not necessarily have more specialist home care. This may be because the two types of service are complementary. Specialist nurses may have more contact with families during hospital admissions and at outpatient review, carrying out home visits more to advise and support parents than to give practical care. General home care nurses may have more contact with families during home visits and give more practical care themselves.

In districts where home care services are not provided locally, a few children may obtain access to specialist support if they are referred to a regional centre. Others may be cared for by services working with adults, such as diabetes liaison nurses. In other instances, extra responsibilities may be taken by primary care staff, parents may depend on ad hoc ward attendance, ${ }^{20}$ or children may simply spend longer in hospital.

Most home care services employed small numbers of highly qualified staff and few provided a 24 hour service. They were probably dealing with small numbers of children in comparison with the total hospital workload. Our previous study of a home care team with four nurses found that referrals were received for $3 \%$ of children discharged from the main referring hospital. ${ }^{4}$ In the present study, differences in the amount and type of home care provided in different places may have been due to variation in need as well as to prioritisation of the service to different patient groups.

In some districts there may also have been difficulties in developing and funding home care services. It has been suggested that home care could be funded by making savings from existing services. ${ }^{2}$ Our survey found a variety of funding sources, including hospital and community budgets as well as charities, inner city grants, and local fundraising. The disadvantage of charitable and other grants is that they are usually short term and their expiry creates a further demand for funding. Ultimately home care must be purchased in the same way as any other service.

Most home care services lacked an identified budget within that of the hospital or community unit where they were based, and in some cases there were problems in obtaining supplies. Although a national policy exists for prescribing for patients discharged from hospital, ${ }^{21}$ the lack of a policy for non-prescribable supplies and equipment has been identified in paediatric home parenteral nutrition ${ }^{13}$ and affects many other chronically ill children, particularly when treatment has been initiated by a tertiary hospital. The provision of supplies and equipment must be included in all contracts for home care.

The boundary between hospital and community can create a barrier to the efficient and effective management of the sick child. ${ }^{5}$ Paediatric home care in the UK has entered a period of rapid growth and may help this barrier to be broken down.

MT holds a MRC Health Services Research Training Fellowship. We thank the Wolfson Foundations for funding the Wolfson Child Health Monitoring Unit and Professor CS Peckham for commenting on an earlier draft.

1 Henderson J, Goldacre MJ, Fairweather JM, Marcovitch H Conditions accounting for substantial time in hospital in children aged 1-14 years. Arch Dis Child 1992; 67: 83-6.

2 Audit Commission. Children first. London: HMSO, 1993.

3 Lessing D, Tatman MA. Paediatric home care in the $1990 \mathrm{~s}$ Arch Dis Child 1991; 66: 994-6.

4 Tatman MA, Woodroffe C, Kelly PJ, Harris RJ. Paediatric home care in Tower Hamlets: a working partnership with parents. Quality in Health Care 1992; 1: 98-103.

5 Thornes R. Bridging the gaps: an exploratory study of the interfaces between primary and specialist care for children within the health services. London: Action for Sick Children on behalf health services. London: Action for Sick Children on beh

6 British Paediatric Association. Handbook. London: BPA 1991-2.

7 Institute of Health Services Management. The hospitals and health services year book. London: IHSM, 1991.

8 Henderson J, Goldacre M, Griffith M. Time spent in hospital by children: trends in the Oxford record linkage study area. Health Trends 1990/1; 4: 166-9.

9 Thornes R. Fust for the day. London: NAWCH on behalf of Caring for Children in the Health Services, 1991.

10 Marcovitch H. Day case treatment for children. Arch Dis Child 1991; 66: 734-6.

11 Department of Health. Welfare of children and young people in hospital. London: HMSO, 1991: para 3.24.

12 Angell C. Equipment requirements for community based paediatric oxygen treatment. Arch Dis Child 1991; 66: 755 .

13 Bisset WM, Stapleford P, Long S, Chamberlain A, Sokel B Milla PJ. Home parenteral nutrition in chronic intestina failure. Arch Dis Child 1992; 67: 109-14.

14 Childs HJ, Dezateux CA. A national survey of nebuliser use. Arch Dis Child 1991; 66: 1351-3.

15 Hill AM. Trends in paediatric medical admissions. $B M F$ 1989; 298: 1479-83.

16 Burney PGJ, Chinn S, Rona RJ. Has the prevalence of asthma increased in children? Evidence from the national study of health and growth 1973-86. BMF 1990; 300: 1306-10. 
17 Alberman E, Botting B. Trends in prevalence and survival of very low birthweight infants, Englan

8 Birch JM, Maraden HB, Morris Jones PH, Pearson D, Blair

$V$. Improvements in survival in childhood cancer: $\checkmark$. Improvements in survival in childhood cancer: results of a population based survey over 30 years. BMF 1988;

19 Britton J. Effects of social class, sex, and region of residence on age at death from cystic fibrosis. BMF 1989; 298: 483-7.

20 Thornes $\mathrm{R}$. Hidden children: an analysis of ward attenders in children's wards. London: Caring for Children in the Health Services, 1988.

21 NHS Management Executive. Responsibility for prescribing between hospitals and GPs. London: NHSME, 1991. (EL (91) 127).

\section{Cats in Connecticut}

Cat scratch disease is usually a benign illness with spontaneous recovery within six to eight weeks but towards the end of 1991 two schoolchildren in Connecticut developed encephalitis from it. This led to a survey of the disease in the state of Connecticut and the results were published in the New England fournal of Medicine (Kenneth M Zangwill and colleagues, 1993; 329: 8-13).

Sixty cases of clinically diagnosed cat scratch disease were identified, the patients ranging in age from 1 to 57 years (mean 15 years). Fifty seven per cent were aged 20 years or less. The incidence was estimated to be 1.8 per 100000 population. All of the patients owned cats and suffered from lymphadenopathy, most commonly in the axillae or neck. Four suffered from encephalopathy but all recovered.

A case-control study included 56 patients and age matched, cat owning controls. Factors strongly associated with cat scratch disease were owning a kitten, being scratched or bitten by a kitten, and owning a kitten with fleas.

Serological testing for antibodies to Rochalimaea henselae was positive in 38 of $\mathbf{4 5}$ patients tested and in four of 112 laboratory control sera. Antibody titres were highest in the first four weeks of the disease and declined over about six months. Eighty one per cent of patients' cats and $38 \%$ of control cats had positive serological tests. In the diagnosis of cat scratch disease a serum titre of antibodies to $R$ henselae of 1 in 64 or more has a sensitivity of $84 \%$, a specificity of $96 \%$, and a positive predictive value of $91 \%$.

The authors suggest that their data indicate a possible role for fleas as a vector of this disease.

ARCHIVIST 